\title{
Dietary fat source regulates $o b$ gene expression in white adipose tissue of rats under hyperphagic feeding
}

\author{
Víctor M. Rodríguez ${ }^{1}$, Catalina Picó ${ }^{2}$, María P. Portillo ${ }^{1} *$, M. Teresa Macarulla ${ }^{1}$ and Andreu Palou ${ }^{2}$ \\ ${ }^{1}$ Department of Nutrition and Food Science, University of País Vasco, Paseo de la Universidad 7, 01006 Vitoria, Spain \\ ${ }^{2}$ Department of Biologia Fonamental i Ciènces de la Salut, Universitat de les Illes Balears, Carretera Valldemossa Km 7.5, \\ 07071 Palma de Mallorca, Spain
}

(Received 6 August 2001 - Revised 2 January 2002 - Accepted 19 January 2002)

\begin{abstract}
This work was designed to investigate the effect of different lipid sources on $o b$ gene expression and serum leptin levels in rats with two different feeding protocols: (1) free access to food; or (2) energy-controlled feeding. Male Wistar rats were fed diets containing $40 \%$ energy as fat (olive oil, sunflower oil or beef tallow), for 4 weeks. In Expt 1 rats had free access to food, and in Expt 2 rats were fed a controlled amount of food $(16 \mathrm{~g} / \mathrm{d}$, equivalent to $300 \mathrm{~kJ} / \mathrm{d})$. Insulin and leptin were determined by ELISA and $o b$ mRNA by Northern blot. When rats had free access to food, $o b$ mRNA levels were higher in animals fed either olive oil or sunflower oil than in those fed beef tallow. In marked contrast with feeding ad libitum, no differences were found among dietary fat groups in rats fed energy-controlled diets. When both feeding protocols were compared, free access to food induced an increased expression of $o b$ mRNA in perirenal and/or epididymal adipose tissues from rats fed either olive oil or sunflower oil, but not from rats fed beef tallow. Dietary lipid type did not induce modifications in serum leptin concentrations. A tendency to higher serum leptin levels was observed more in rats with free access to food than in rats fed energy-controlled feeding. No differences were found in insulin levels. Dietary fat type importantly affects $o b$ mRNA expression in rat white adipose tissue under hyperphagic conditions. Further study is needed in order to elucidate the mechanism underlying this effect.
\end{abstract}

$o b$ gene: Leptin: Dietary fat: Adipose tissue

Leptin, the product of the $o b$ gene, is a hormone produced mainly by white adipose tissue, secreted into blood and transported into the brain via a saturable system, where it releases or inhibits factors that ultimately reduce energy intake and increase energy expenditure (Ahima \& Flier, 2000; Palou et al. 2000).

Many studies have shown a positive correlation between leptin levels and body fat both in human subjects (Considine et al. 1996; Havel et al. 1996) and rodents (Frederich et al. 1995; Maffei et al. 1995). Thus, this protein has been suggested as an 'adipostat' to signal the state of body triacylglycerol stores to the brain, an important feed-back which is necessary for precise regulation of long-term energy balance (Ahima \& Flier, 2000). A role for leptin in the short-term control of energy balance has also been suggested (Bado et al. 1998; Cinti et al. 2000).

Dietary manipulations appear to influence leptin secretion through mechanisms other than just by altering total fat mass. It has been demonstrated that factors such as food restriction (Cha \& Jones, 1998), carbohydrate intake (Jenkins et al. 1997) and fasting (Trayhurn et al. $1995 b$ ) induce changes in circulating level concentrations.

It has been shown that dietary fatty acid composition can influence different integrating processes of lipid metabolism, such as adipose tissue lipolysis (Awad \& Chattopahyay 1986a,b; Raclot et al. 1997; Portillo et al. 1999b), lipogenesis (Perdereau et al. 1992; Camara et al. 1996; Portillo et al. 2001), lipoprotein lipase activity (Murphy et al. 1993; Raclot et al. 1997), thermogenic capacity (Takeuchi et al. 1995; Kawada et al. 1998; Takahashi \& Ide, 2000; Rodríguez et al. 2002) and fatty acid oxidation (Leyton et al. 1987). The potential influence of dietary fatty acids on expression of $o b$ gene and secretion of leptin remains to be elucidated.

The aim of the present study was to investigate the effect of different lipid sources, olive oil (a vegetal oil rich in monounsaturated fatty acids), sunflower oil (a vegetal oil rich in polyunsaturated fatty acids) and beef tallow (an 
animal fat rich in saturated fatty acids) on $o b$ gene expression and serum leptin levels in rats on two different feeding protocols: (1) free access to food: or (2) energycontrolled feeding. Due to the fact that differences in $o b$ gene expression among adipose tissues from different anatomical locations have been demonstrated (Trayhurn et al. $1995 \mathrm{~b}$; Oliver et al. 2001), the possibility of a different pattern of response to dietary fat in different fat depots should not be discarded. In order to test this hypothesis analysis of perirenal and epididymal depots was carried out, depots, which have a relatively high expression of this gene.

\section{Material and methods}

\section{Animals, diets and experimental design}

The experiment was conducted in male Wistar rats (8week-old) purchased from IFFA-Credo (Barcelona, Spain), that were adapted to the room and cage environment $4 \mathrm{~d}$ before the beginning of the protocol. They were housed individually in polycarbonate metabolic cages (Tecniplast Gazzada, Guggugiate, Italy) and maintained in a temperature $\left(23 \pm 2^{\circ} \mathrm{C}\right)$ and humidity $(50 \%)$-controlled room with $12 \mathrm{~h}$ light-dark cycle, lights on at 08.00 hours.

When animals $(n 60)$ reached a body weight of 240 (SEM 2) $\mathrm{g}$, they were randomly divided into six groups ( $n 10$ per group). Three groups were used for Expt 1, in which rats had free access to diets that provided different lipid sources for 4 weeks. Daily determination of food intake was carried out.

The remaining three groups were used for Expt 2. In order to prevent a spontaneous hyperphagia due to the high content of fat and sucrose of the experimental diets, each rat was given $16 \mathrm{~g}(300 \mathrm{~kJ})$ of the same diets as those used in Expt $1 / \mathrm{d}$, for 4 weeks. This amount was equivalent to the spontaneous energy intake observed in a pilot study where rats with a similar mean body weight to that of rats in this present study were fed a laboratory chow diet. Potential differences among dietary fat groups

Table 1. Composition of experimental diets

\begin{tabular}{lccc}
\hline Diet... & Olive oil & Sunflower oil & Beef tallow \\
\hline Ingredients (g/kg) & & & \\
Casein* & 200 & 200 & 200 \\
DL-Methionine & 4 & 4 & 4 \\
Sucrose & 244 & 244 & 244 \\
Wheat starch & 245 & 245 & 245 \\
Olive oil & 200 & - & - \\
Sunflower oil & - & 200 & 10 \\
Beef tallow & - & - & 190 \\
Cellulose & 50 & 50 & 50 \\
Mineral mix $†$ & 45 & 45 & 45 \\
Vitamin mix† & 10 & 10 & 10 \\
Choline chloride salt & 2 & 2 & 2 \\
Total energy (MJ/kg) & 18.8 & $18 \cdot 8$ & 18.8 \\
Composition by energy (\%) & & & \\
$\quad$ Protein & 16.4 & 16.4 & 16.4 \\
Lipid & 40.1 & $40 \cdot 1$ & $40 \cdot 1$ \\
Carbohydrate & 43.5 & 43.5 & 43.5 \\
\hline
\end{tabular}

${ }^{*} 900 \mathrm{~g}$ casein $/ \mathrm{kg}$.

†Formulated according to AIN-93 recommendations (Reeves et al. 1993). in energy intake and possible obesity were avoided. All rats had free access to water.

The experimental diets were freshly prepared once per week, gassed with $\mathrm{N}_{2}$ and stored at $0-4^{\circ} \mathrm{C}$ to avoid rancidity. The composition of all diets are described in Table 1 . The fats used were olive oil, sunflower oil and beef tallow; they represented $40 \%$ total energy. Dietary supply of vitamins, minerals and protein was in accordance with dietary recommended allowances for rats from the American Institute of Nutrition AIN-93 (Reeves et al. 1993). The fatty acid composition of the diets was determined by GC and is shown in Table 2. The beef-tallow diet was supplemented with sunflower oil $(10 \mathrm{~g} / \mathrm{kg}$ diet $)$ to maintain an adequate intake of linoleic acid and to avoid growth alterations due to the linoleic acid deficiency (Cunnane \& Anderson, 1997). The dietary oils were obtained from local markets, vitamins and minerals were purchased from Dyєts (Bethlehem, USA) and casein from Sigma (Barcelona, Spain).

At the end of the feeding period, and after an overnight fast, animals were weighed. After anaesthesia for body-fat measurement, they were decapitated. Blood was collected and centrifuged and adipose tissues from perirenal and epididymal anatomical locations were dissected and weighed. Serum and tissue samples were immediately frozen in liquid $\mathrm{N}_{2}$ and stored $\left(-80^{\circ} \mathrm{C}\right)$ for subsequent analyses.

\section{Fatty acid composition of dietary lipid sources}

The oils and the beef tallow were transmethylated with methanol in $\mathrm{H}_{2} \mathrm{SO}_{4}$. Analysis of fatty acids was conducted using a HP 6890 Series II GC equipped with flame ionization detector and a $30 \mathrm{~m} \times 320 \mu \mathrm{m}$ HP $19091 \mathrm{~N}-213$ PEG capillary column (HP Innowax) (Hewlett-Packard, Avondale, PA, USA). The carrier gas was $\mathrm{N}_{2}$ at a flow rate of $1 \mathrm{ml} / \mathrm{min}$. The temperatures of the oven and the injection port were maintained at $170^{\circ} \mathrm{C}$ and $225^{\circ} \mathrm{C}$ respectively. Peaks were identified using fatty acid methyl esters standards obtained from Sigma. All samples were analysed in quadruplicate. The replicate error (CV) was $5 \%$ or less of the mean for all fatty acids.

Table 2. Fatty acid composition of dietary fats $(\mathrm{g} / 100 \mathrm{~g}$ total fatty acids) ${ }^{*}$

\begin{tabular}{|c|c|c|c|}
\hline Fatty acids & Olive oil & Sunflower oil & Beef tallow \\
\hline $12: 0$ & $<0.10$ & $<0.10$ & 0.20 \\
\hline $14: 0$ & $<0.10$ & 0.10 & 4.89 \\
\hline $14: 1 n-5$ & $<0.10$ & $<0.10$ & 0.60 \\
\hline $16: 0$ & $11 \cdot 87$ & $6 \cdot 13$ & $29 \cdot 33$ \\
\hline $16: 1 n-7$ & 0.94 & 0.11 & 2.69 \\
\hline $18: 0$ & 2.92 & 4.60 & $24 \cdot 21$ \\
\hline $18: 1 n-9$ & $72 \cdot 80$ & 24.76 & 33.77 \\
\hline $18: 1 n-7$ & 4.46 & 1.51 & 1.75 \\
\hline $18: 2 n-6$ & $5 \cdot 69$ & 61.74 & 1.91 \\
\hline $18: 3 n-3$ & 0.50 & 0.10 & 0.30 \\
\hline $20: 0$ & 0.39 & 0.29 & $<0.10$ \\
\hline$\sum$ Saturates & $15 \cdot 18$ & 11.12 & 58.63 \\
\hline$\Sigma$ Monounsaturates & 78.20 & $26 \cdot 38$ & 38.81 \\
\hline$\Sigma$ Polyunsaturates & 6.19 & 61.84 & $2 \cdot 21$ \\
\hline
\end{tabular}

* Only fatty acids detected at levels $>0.10 \mathrm{~g} / 100 \mathrm{~g}$ total fatty acids are listed. 


\section{Total body fat}

Body composition was assessed in anaesthetized rats before killing by using an EM-SCAN TOBEC SA-3000 (EM-SCAN Inc., Springfield, IL, USA). Measures were based on energy absorption in the presence of a radio-frequency electromagnetic field.

\section{Northern blot analysis of $o b m R N A$}

Adipose tissue RNA were extracted with Tripure Isolation reagent. Total RNA $(20 \mu \mathrm{g})$ was size fractionated in denaturing formaldehyde $(180 \mathrm{ml} / \mathrm{l})$ agarose $(12 \mathrm{~g} / \mathrm{l})$ gel. RNA was transferred onto nylon membranes with $20 \times \mathrm{SSC}$ (saline sodium citrate) and u.v. cross-linked.

Membranes were prehybridizated at $42^{\circ} \mathrm{C}$ with DYG Easy Hyb solution and hybridizated overnight at $42^{\circ} \mathrm{C}$ in the same solution containing the 33-mer antisense oligonucleotide $o b$ probes $5^{\prime}$-CGTCTGAGGCAGGGAGCAGCTCTTGGAGAAGGC-3' (34 ng/ml), synthesized commercially and labelled with a single digoxigenin ligand (Trayhurn et al. $1995 a$ ). They were then washed twice with $2 \times$ SSC SDS $(1 \mathrm{~g} / \mathrm{l})$ at room temperature and after that twice with $0.1 \times \operatorname{SSC} \operatorname{SDS}(1 \mathrm{~g} / 1)$ at $48^{\circ} \mathrm{C}$. Membranes were then blocked with blocking reagent solution $(10 \mathrm{ml} / 1$ maleic acid buffer) and then incubated with phosphatase alkaline labelled anti-digoxigenin. CDP-Star substrate was used to produce a chemiluminescence signal, and the membranes were exposed to hyperfilm ECL films (Amersham International; Amersham, Bucks, UK). Signals obtained were analysed by scanner photodensitometry and quantified using the Bio Image software (Millipore; Belford, MA, USA).

Finally, blots were stripped by exposure to boiling SDS ( $1 \mathrm{~g} / \mathrm{l})$ and re-probed for $18 \mathrm{~S}$ rRNA to check the loading and transfer of RNA during blotting. For $18 \mathrm{~S}$ rRNA detection, the 31-mer digoxigenin-labelled antisense oligonucleotide $5^{\prime}$ CGCCTGCTGCCTTCCTTGGATGTGGTAGCCG-3' at a concentration of $70 \mathrm{pg} / \mathrm{mL}$ was used (Trayhurn et al. 1995a).
The RNA isolation reagent, nylon membranes, and reagents for Northern blotting, if not indicated, were purchased from Roche Applied Science (Mannheim, Germany).

\section{Serum analyses}

Insulin and leptin were determined using commercial kits by ELISA Rat Insulin ELISA, DRG Instruments $\mathrm{GmbH}$, Marburg, Germany, and Quantikine M Murine kit, R\&D Systems, Minneapolis, MN, USA respectively.

\section{Statistical analysis}

Statistical analysis was performed using SPSS 8.0 (SPSS Inc., Chicago, IL, USA). ANOVA was used to analyse the data. A post hoc test, using the Newman-Keuls method was performed when appropriate. Differences between means were considered to be significant at $P<0.05$ The results are expressed as means values with their standard errors.

\section{Results}

Body weight, weight gain, food consumption, adipose tissue weights and total body fat

Final body weight, weight gain and food intake values are shown in Table 3. Adipose tissue weights from perirenal and epididymal anatomical locations and total body fat are shown in Table 4.

In Expt 1, animals fed the different lipid sources gained comparable amounts of weight during the experimental period. No differences in adipose tissue weights and total body fat were found between dietary fat groups. In Expt 2 , despite the isoenergetic feeding, rats fed the beeftallow diet gained significantly less weight than rats fed the other two diets $(P<0 \cdot 05)$. In contrast, no significant differences were found between rats fed the olive-oil and

Table 3. Effects of dietary fat source on body weight, food intake and on serum insulin and leptin levels in rats fed either ad libitum or energy-controlled diets $\dagger$

(Mean values with their standard errors for ten rats per group)

\begin{tabular}{|c|c|c|c|c|c|c|}
\hline \multirow[t]{2}{*}{ Diet... } & \multicolumn{2}{|c|}{ Olive oil } & \multicolumn{2}{|c|}{ Sunflower oil } & \multicolumn{2}{|c|}{ Beef tallow } \\
\hline & Mean & SEM & Mean & SEM & Mean & SEM \\
\hline \multicolumn{7}{|l|}{ Rats fed ad libitum } \\
\hline Final body weight $(\mathrm{g})$ & 374 & 5 & 370 & 4 & 371 & 5 \\
\hline Body weight gain $(\mathrm{g})$ & 135 & 6 & 133 & 5 & 139 & 8 \\
\hline Food intake $(\mathrm{g} / \mathrm{d})$ & $21 \cdot 1^{\mathrm{b}}$ & 0.5 & $20.7^{\mathrm{b}}$ & 0.4 & $23 \cdot 3^{a}$ & 0.5 \\
\hline Insulin (pmol/l) & 265 & 23 & 220 & 12 & 242 & 13 \\
\hline Leptin (ng/ml) & 9.94 & 1.00 & $10 \cdot 89$ & $1 \cdot 18$ & $9 \cdot 25$ & $2 \cdot 31$ \\
\hline \multicolumn{7}{|c|}{ Rats fed energy-controlled diet } \\
\hline Final body weight $(\mathrm{g})$ & $331^{a *}$ & 4 & $340^{a *}$ & 2 & $315^{\mathrm{b} *}$ & 4 \\
\hline Body weight gain (g) & $88^{\mathrm{a} *}$ & 4 & $96^{a_{*}}$ & 3 & $72^{\mathrm{b} *}$ & 4 \\
\hline Food intake $(\mathrm{g} / \mathrm{d})$ & $16 \cdot 0^{*}$ & 0.0 & $16 \cdot 0^{*}$ & 0.0 & $16 \cdot 0^{\star}$ & 0.0 \\
\hline Insulin (pmol/l) & 208 & 7 & 202 & 7 & 246 & 16 \\
\hline Leptin (ng/ml) & $6 \cdot 12$ & 1.49 & 6.95 & 1.61 & 5.46 & 1.87 \\
\hline
\end{tabular}

${ }^{\mathrm{a}, \mathrm{b}}$ Mean values within a row with unlike superscript letters were significantly different $(P<0.05)$.

Mean values were significantly different from those of the groups fed ad libitum for each dietary fat source: ${ }^{*} P<0.05$.

†For details of diets and procedures see Tables 1 and 2 and p. 428. 
Table 4. Effects of dietary fat source on adipose tissue weights and on total body fat in rats fed either ad libitum or energy-controlled diet†

(Mean values with their standard errors for ten rats per group)

\begin{tabular}{|c|c|c|c|c|c|c|}
\hline \multirow[t]{2}{*}{ Diet... } & \multicolumn{2}{|c|}{ Olive oil } & \multicolumn{2}{|c|}{ Sunflower oil } & \multicolumn{2}{|c|}{ Beef tallow } \\
\hline & Mean & SEM & Mean & SEM & Mean & SEM \\
\hline \multicolumn{7}{|l|}{ Rats fed ad libitum } \\
\hline Perirenal adipose tissue $(\mathrm{g})$ & 7.95 & 0.60 & $7 \cdot 80$ & 0.43 & 7.89 & 0.41 \\
\hline Epididymal adipose tissue ( $\mathrm{g}$ ) & $8 \cdot 11$ & 0.55 & $6 \cdot 86$ & 0.65 & 8.42 & 0.66 \\
\hline Total body fat $(\mathrm{g})$ & $72 \cdot 70$ & $2 \cdot 41$ & 68.03 & 3.00 & 68.46 & 2.63 \\
\hline \multicolumn{7}{|l|}{ Rats fed energy-controlled diet } \\
\hline Perirenal adipose tissue $(\mathrm{g})$ & $5 \cdot 22^{a b_{*}}$ & 0.33 & $6 \cdot 29^{a}$ & 0.63 & $4.33^{b *}$ & 0.53 \\
\hline Epididymal adipose tissue ( $(\mathrm{g})$ & $5 \cdot 40^{\mathrm{a} *}$ & 0.27 & $5 \cdot 48^{a}$ & 0.42 & $4 \cdot 29^{b *}$ & 0.38 \\
\hline Total body fat $(\mathrm{g})$ & $38.43^{\mathrm{ab} *}$ & 1.48 & $42 \cdot 80^{a *}$ & 1.54 & $35.79^{b *}$ & 1.29 \\
\hline
\end{tabular}

a,b Mean values within a row with unlike superscript letters were significantly different $(P<0.05)$.

Mean values were significantly different from those of the groups fed ad libitum for each dietary fat source: ${ }^{*} P<0.05$.

†For details of diets and procedures, see Tables 1 and 2 and p. 428.

the sunflower-oil diets. Beef tallow-fed rats showed the lowest values for perirenal and epididymal adipose tissues and total body fat.

When rats had free access to food there was a main effect of the type of fat on food intake, with those rats eating the saturated fat having a higher food intake than those rats eating unsaturated fats $(P<0.05)$. Under this feeding protocol, a significant increase in food consumption was induced for all the dietary fat sources as compared with rats fed controlled amounts of diets $(P<0 \cdot 001)$.

\section{Northern blot analysis of ob mRNA in white adipose tissues}

When rats had free access to food, $o b$ mRNA levels were higher in animals fed either olive oil or sunflower oil than in those fed beef tallow in both perirenal and epididymal adipose tissues $(P<0 \cdot 05)$ (Fig. 1). In contrast to feeding ad libitum, no differences were found among dietary fat groups in rats fed energy-controlled diets (Fig. 2).

\section{Serum variables}

Serum levels of leptin and insulin are shown in Table 3. Dietary lipid type did not induce modifications in these variables. By comparing feeding ad libitum with energycontrolled feeding for each dietary fat type, a tendency to higher leptin levels was observed in rats with free access to food, but this increase did not reach statistical significance. In contrast, when the three dietary fat type groups were pooled for each feeding protocol, serum leptin levels were significantly higher in rats fed ad libitum than in rats fed energy-controlled diets $(P<0 \cdot 01)$.

Linear regression analyses were performed for circulating leptin levels $v$. adipose tissue weights, total body fat, body weight and serum insulin levels. Significant positive

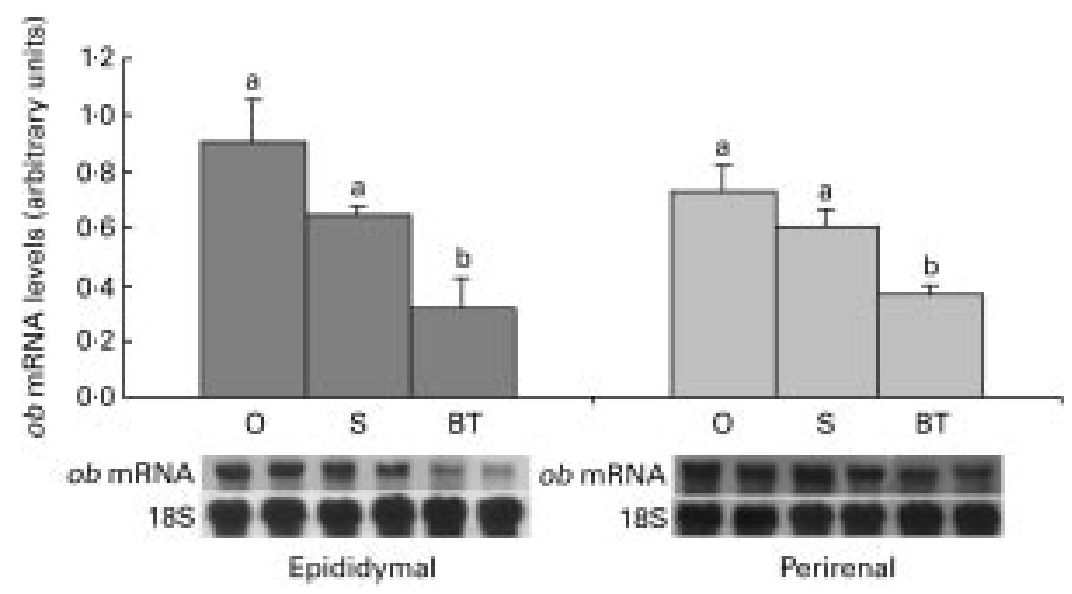

Fig. 1. ob mRNA expression in epididymal and perirenal adipose tissues from rats fed different lipid sources ad libitum. ob mRNA was measured by Northern blot and expressed relative to $18 \mathrm{~S}$ rRNA in arbitrary units. O, olive oil; S, sunflower oil; BT, beef tallow. For details of diets and procedures, see Tables 1 and 2 and p. 428. Values are means for ten rats per group with standard errors shown by vertical bars. ${ }^{a, b}$ Mean values with unlilke superscript letters were significantly different $(P<0.05)$. 


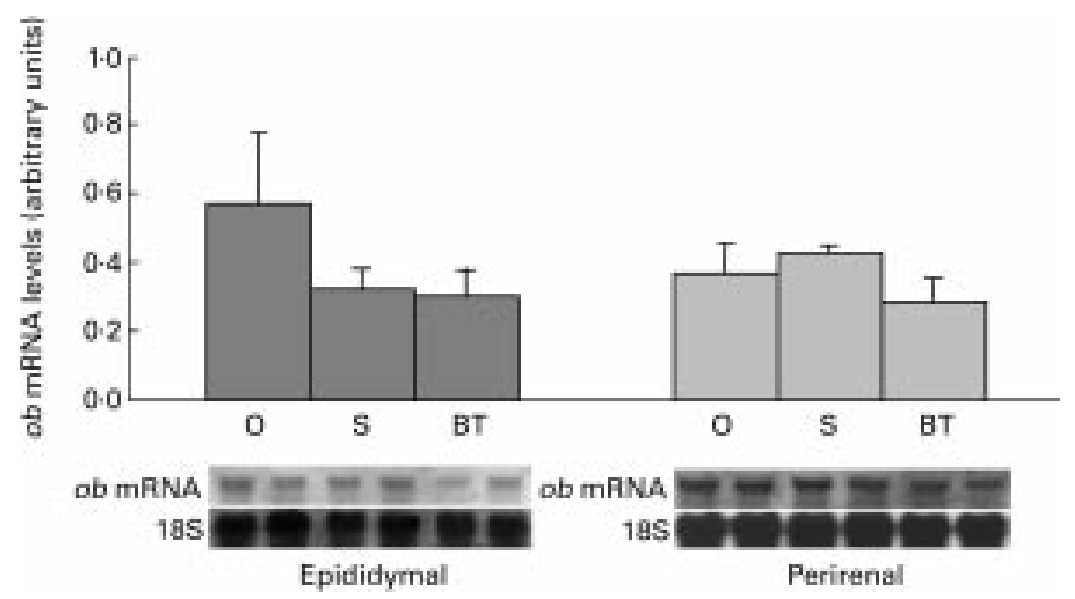

Fig. 2. $o b$ mRNA expression in epididymal and perirenal adipose tissues from rats fed energy-controlled diets that provided different lipid sources. ob mRNA was measured by Northern blot and expressed relative to $18 \mathrm{~S}$ rRNA in arbitrary units. O, olive oil; S, sunflower oil; BT, beef tallow. For details of diets and procedures, see Tables 1 and 2 and p. 428. Values are means for ten rats per group with standard errors shown by vertical bars. There were no significant differences between the dietary groups.

correlations were found when the six experimental groups were pooled ( $n 6$ per group) for body weight $(r$ 0.470, $P=0.008)$, epididymal adipose tissue $(r 0.398, P=0.027)$ and total body fat $(r 0.443, P=0 \cdot 012)$.

\section{Discussion}

When rats had free access to food, dietary lipid source did not influence body-weight gain, adipose tissue weights or total fat accumulation. Nevertheless, significant differences in food intake were found; rats eating the saturated fat showed higher food intake than those rats eating unsaturated fats $(P<0 \cdot 05)$. This suggests different utilization of dietary fats. In a previous study we found that unsaturated fats were better absorbed than saturated fats; absorbability coefficients were $98.2,97.4$ and $93.7 \%$ for olive oil, sunflower oil and beef tallow respectively (Portillo et al. 2001). This situation can help to explain the similarity in final body weights and adipose depot sizes among the three groups, despite some differences in food intake.

In Expt 2 rats were fed a fixed amount of the experimental diets $(16 \mathrm{~g} / \mathrm{d}, 300 \mathrm{~kJ} / \mathrm{d})$, providing adequate energy to ensure a normal growth, as explained on p. 428. This protocol removed the differences in food consumption produced in Expt 1 and avoids the energy hyperphagia induced by high-fat feeding. This hyperphagic effect has been described well in the literature (Lim et al. 1991; Astrup et al. 1994; Portillo et al. 1998, 1999a). In the present study, energy intake in rats with free access to food was $29.4-45.6 \%$ higher than that of rats fed in a controlled way. Although in the second experiment energy intake was the same in the four groups, the reduced amount of fat absorbed fat by the beef tallow-fed group $(P<0 \cdot 05)$ resulted in an energy deficiency that can explain the lower weight gain and fat accumulation observed in this group (Portillo et al. 2001). As expected, and due to higher energy intake, adipose tissue weights and total body fat were higher in rats with free access to food than in rats fed energy-controlled diets.

Information concerning the effects of dietary lipid sources or fatty acids on $o b$ mRNA expression is scarce. Raclot et al. (1997) observed that a diet rich in oleic acid elicited a higher $o b$ mRNA expression in rat adipose tissue than a fish-oil diet, rich in $n-3$ fatty acids. Murata et al. (2000) analysed the effects of different doses of eicosapentaenoic acid on cultured 3T3-L1 adipocytes in vitro; they demonstrated that this fatty acid caused a time and dose-dependent increase in $o b$ mRNA.

The results of the present study demonstrate that only under hyperphagic conditions was leptin gene expression in rat white adipose tissue affected by dietary fat source. It could be hypothesized that, in the absence of energy excess, energy intake was more significant in the control of leptin than the quality of dietary fat. However, when feeding ad libitum, fatty acid composition of the diet does affect $o b$ mRNA expression: unsaturated fatty aciddiet feeding led to higher $o b$ mRNA expression than saturated fatty acid-diet feeding. The existence of changes in $o b$ mRNA induced by dietary fat type in ad libitum-fed rats without changes in adipose tissue size suggests that dietary fat acts in a way independent of this variable. Cha \& Jones (1998) also observed the influence of energy intake on dietary fat effects. They found that dietary fat consumed by rats for 10 weeks modified serum leptin levels when rats were fed ad libitum, but not when animals were fed a diet restricted to $70 \%$ of ad libitum energy intake.

The mechanisms responsible for the effect of dietary fat type on $o b$ mRNA gene expression are not clear. In a previous work (Perona et al. 2000) where the same experimental design was used, we observed significant differences in the fatty acid profiles of triacylglycerol stored in adipose tissue depending on dietary fat source. In this context, it could be speculated that the saturated 
fatty acids deposited in adipose tissue from rats fed beef tallow $(35.4 \mathrm{~g} / 100 \mathrm{~g}$ of total fat for perirenal adipose tissue), the monounsaturated fatty acids deposited in adipose tissue from olive oil-fed rats $(68.0 \mathrm{~g} / 100 \mathrm{~g}$ of total fat for perirenal adipose tissue) or the $n-6$ polyunsaturated fatty acids deposited in adipose tissue from sunflower fed rats $(46.4 \mathrm{~g} / 100 \mathrm{~g}$ total fat for perirenal adipose tissue) may each have an effect that either inhibits or increases leptin gene expression. Nevertheless if this were the case, differences among groups fed energy-controlled diets would have been observed.

Recent reports suggest that the hexosamine biosynthetic pathway contributes to the fatty acid regulation of leptin expression (Wang et al. 1998; Murata et al. 2000; Perona et al. 2000). In the present study, experiments designed to clarify this hypothesis have not been carried out. Changes in fatty acid availability that inhibit lipolysis and promote increased flux of fructose 6-phosphate into the glucosamine pathway appear to be important in the regulation of leptin production (Wang et al. 1998). However, the precise role of specific fatty acids or the particular effects of the diets studied as regulators of the glycolysis pathway is not well known.

In addition, the possible role of dietary fatty acids as signalling molecules that bind and activate a new class of nuclear receptors, the peroxisome proliferator-activated receptors could be considered (Nisoli et al. 2000). It has been demonstrated that different ligands for peroxisome proliferator-activated receptors such as clofibrate, troglitazone or thiazolidinediones repress $o b$ mRNA expression (De Vos et al. 1996; Nolan et al. 1996). However, no direct effect for the more abundant fatty acids in the cells has been described as acting on peroxisome proliferator-activated receptors.

Divergences in the pattern of response of $o b$ mRNA levels and circulating leptin concentrations were found. Dietary fat source did not affect serum leptin levels for either feeding ad libitum or in energy-controlled feeding. This discrepancy can be found in the literature. Lin et al. (1998) observed significant differences in epididymal adipose tissue $o b$ mRNA in rats fed either a high-fat diet or a low-fat diet for 5 weeks but no changes in serum leptin concentrations. Several facts could explain these discrepancies. Leptin secreted from several organs addition to white adipose tissue, including the stomach (Cinti et al. 2000, 2001), brown fat, placenta and fetal tissues (such as heart and bone cartilage) (Trayhurn et al. 1999) as well as subcutaneous adipose tissue and the greater fat pad, accounts for serum leptin levels. Villafuerte et al. (2000) reported that, although the expression of $o b$ mRNA in subcutaneous tissue is relatively low, the contribution to total circulating leptin may be proportionally higher because of the absolute mass of the tissue. In the present study, information concerning $o b$ mRNA regulation in tissues mentioned earlier and organs is not available. On the other hand, differences in the clearance of leptin from circulation due to binding to its soluble receptor should not be discarded. Secretion and/ or turnover of leptin may be regulated independently of synthesis.

It has been demonstrated that leptin levels increase as the size of adipose tissue increases (Frederich et al.
1995; Maffei et al. 1995; Considine et al. 1996). An increase in energy intake also results in a sharp increase in serum leptin levels, even in the absence of body weight changes (Kolaczynski et al. 1996a; Sinha et al. 1996). In the present study, rats fed ad libitum showed higher values of serum leptin than those showed by rats fed energy-controlled diets, although when considering each dietary fat individually differences did not reach statistical significance. On the other hand, under energycontrolled feeding, rats fed the beef-tallow diet showed significantly lower weights of adipose tissues than rats fed the other two diets, as well as a tendency towards lower serum leptin levels $(10.8 \%$ lower than olive oil-fed rats and $21.4 \%$ lower than sunflower oil-fed rats). It is important to point out that serum analyses were carried out after an overnight fast. It has been widely proved that fasting results in a rapid and drastic fall in circulating leptin (Trayhurn et al. 1995b; Hardie et al. 1996; Kolaczynski et al. 1996b). Thus, this fasting-induced effect might partially mask the effects of increased energy intake and adiposity in rats fed ad libitum. A positive and significant correlation was found between leptin levels and body weight, adipose tissue weights and total body fat in concordance with other studies (Frederich et al. 1995; Maffei et al. 1995).

The role of hormones in the regulation of leptin expression has been intensively explored. A prime candidate for such regulation is insulin. In rats, this hormone stimulates $o b$ gene expression and leptin production (Cusin et al. 1995; Saladin et al. 1995). In order to test whether insulin was involved in the dietary fat type effects found in this study, serum concentrations were measured. However, differences in $o b$ mRNA levels in adipose tissue cannot be explained by changes in insulin status because no significant differences were found among rats fed the three different lipid sources.

In summary, under high-fat ad libitum feeding conditions, the expression of $o b$ mRNA in white adipose tissue from rats is enhanced by unsaturated dietary fats (olive oil and sunflower oil) compared with a saturated dietary fat (beef tallow) by a mechanism which is independent of adipose tissue size. The mechanisms underlying this effect remain unclear, so further study is required in order to shed light on this issue.

\section{Acknowledgements}

This study was supported by the Government of the País Vasco (grant PI 96/22 to M.P.P.), DGICYT, Ministerio de Educación y Ciencia, Spain (grant PM97-0094 to A.P.) and by the European Commission DGXII (COST 918 to A.P.). V.M.R. is a recipient of a fellowship from the Spanish Government.

\section{References}

Ahima RS \& Flier JS (2000) Leptin. Annual Review of Physiology 62, 413-437.

Astrup A, Buemann B, Western P, Toubro S, Raven A \& Christensen NJ (1994) Obesity as an adaptation to a high-fat 
diet: evidence from a cross-sectional study. American Journal of Clinical Nutrition 59, 350-355.

Awad AB \& Chattopahyay JP (1986a) Effect of dietary saturated fatty acids on hormone-sensitive lipolysis in rat adipocytes. Journal of Nutrition 116, 1088-1094.

Awad AB \& Chattopahyay JP (1986b) Effect of dietary saturated fatty acids on intracellular free fatty acids and kinetic properties of hormone-sensitive lipase of rat adipocytes. Journal of Nutrition 116, 1095-1100.

Bado A, Levasseur S, Attoub S, Kermorgant S, Laigneau JP, Bortoluzzi MN, Moizo L, Lehy T, Guerre-Millo M, Le Marchand-Brustel Y \& Lewin MJ (1998) The stomach is a source of leptin. Nature 394, 790-793.

Camara M, Mourot J \& Février C (1996) Influence of two dairy fats on lipid synthesis in the pig: comparative study of liver, muscle and the two backfat layers. Annals of Nutrition and Metabolism 40, 287-295.

Cha MC \& Jones PJH (1998) Dietary type and energy restriction interactively influence plasma leptin concentration in rats. Journal of Lipid Research 39, 1655-1660.

Cinti S, de Matteis R, Ceresi E, Pico C, Oliver J, Oliver P, Palou A, Obrador A \& Maffeis C (2001) Leptin in the human stomach. Gut 49, 155.

Cinti S, Matteis RD, Pico C, Ceresi E, Obrador A, Maffeis C, Oliver J \& Palou A (2000) Secretory granules of endocrine and chief cells of human stomach mucosa contain leptin. International Journal of Obesity 24, 789-793.

Considine RV, Sinha M, Heiman M, Kriauciunas A, Stephens TW, Nyce MR, Ohannesian JP, Marco CC, McKee LJ \& Bauer TL (1996) Serum-immunoreactive-leptin concentrations in normal-weight and obese humans. New England Journal of Medicine 334, 292-295.

Cunnane SC \& Anderson MJ (1997) Pure linoleate deficiency in the rat: influence on growth, accumulation of $n-6$ polyunsaturates and $\left(1-{ }^{14} \mathrm{C}\right]$-linoleate oxidation. Journal of Lipid Research 38, 805-812.

Cusin I, Sainsbury A, Doyle P, Rohner-Jeanreneaud F \& Jeanreneaud B (1995) The $o b$ gene and insulin. A relationship leading to clues to the understanding of obesity. Diabetes $\mathbf{4 4}$, $1467-1470$.

De Vos P, Lefevre AM, Miller SG, Guerre-Millo M, Wong K, Saladin R, Hamann LG, Staels B, Briggs MR \& Auwerx J (1996) Thiazolidinediones repress $o b$ gene expression in rodents via activation of peroxisome proliferator-activated receptor gamma. Journal of Clinical Investigation $\mathbf{9 8}$ 1004-1009.

Frederich RC, Hamann A, Anderson S, Lollmann B, Lowell BB \& Flier JS (1995) Leptin levels reflect body lipid content in mice: Evidence for diet-induced resistance to leptin action. Nature Medicine 1, 1311-1314.

Hardie LJ, Rayner DV, Holmes S \& Trayhurn P (1996) Circulating leptin levels are modulated by fasting, cold exposure and insulin administration in lean but not Zucker $(f a / f a)$ rats as measured by ELISA. Biochemical Biophysical Research Communications 223, 660-665.

Havel PJ, Kasim-Karacas S, Mueller W, Johnson PR, Gingerich RL \& Stern JS (1996) Relationship of plasma leptin to plasma insulin and adiposity in normal weight and overweight women: effects of dietary fat content and sustained weight loss. Journal of Clinical Endocrinology and Metabolism 81, 4406-4413.

Jenkins AB, Markovic TP, Fleury A \& Campbell LV (1997) Carbohydrate intake in short-term regulation of leptin in humans. Diabetologia 40, 348-351.

Kawada T, Kayahasi S, Hida Y, Koga K, Nadachi Y \& Fushiki T (1998) Fish (bonito) oil supplementation enhances the expression of uncoupling protein in brown adipose tissue of rat. Journal of Agriculture and Food Chemistry 46, $1225-1227$.

Kolaczynski JW, Considine RV, Ohannesian JP, Marco CC \& Caro JF (1996a) Response of leptin to short-term and prolonged overfeeding in humans. A link with ketogenesis but not ketones themselves. Diabetes 45, 1511-1515.

Kolaczynski JW, Ohannesian JP, Considine RV, Marco CC \& Caro JF (1996b) Response of leptin to short-term and prolonged overfeeding in humans. Journal of Clinical Endocrinology and Metabolism 81, 4162-4165.

Leyton PJ, Drury PJ \& Crawford MA (1987) Differential oxidation of saturated and unsaturated fatty acids in vivo in rat. British Journal of Nutrition 57, 383-393.

Lim K, Shimomura Y \& Suzuki S (1991) Effect of high-fat diet feeding over generations on body fat accumulation. In Obesity: Dietary Factors and Control, pp. 181-190 [DR Romsos, J Himms-Hagen and M Suzuki, editors]. Basel: Karger.

Lin X, Chavez MR, Bruch RC, Kilroy GE, Simmons LA, Lin L, Braymer HD, Bray GA \& York DA (1998) The effects of a high-fat diet on leptin mRNA, serum and the response to leptin are not altered in a rat strain susceptible to high fat diet induced obesity. Journal of Nutrition 128, $1606-1613$.

Maffei M, Halaas J, Ravussin E, Pratley RE, Lee GH, Zhang Y, Fei H, Kim S, Lallone R \& Ranganathan S (1995) Leptin levels in human and rodent: measurement of plasma level and $o b$ RNA in obese and weight-reduced subjects. Nature Medicine 1, 1151-1161.

Murata M, Kaji H, Takahashi Y, Lida K, Mizuno I, Okimura Y, Abe H \& Chihara K (2000) Stimulation by eicosapentaenoic acids of leptin mRNA expression and its secretion in mouse 3T3-L1 adipocytes in vitro. Biochemical Biophysical Research Communications 270, 343-348.

Murphy MC, Zampelas A, Puddicombe SM, Furlonger NP, Morgan LM \& Williams CM (1993) Pretranslational regulation of the expression of the lipoprotein-lipase $(E C 3 \cdot 1 \cdot 1 \cdot 34)$ gene by dietary fatty acids in the rat. British Journal of Nutrition 70, 727-736.

Nisoli E, Carruba MO, Tonello C, Macor C, Federspil G \& Vettro $\mathrm{R}$ (2000) Induction of fatty acid translocase/CD 36, peroxisome proliferator-activated receptor-gamma 2, leptin, uncoupling proteins 2 and 3 , and tumour necrosis factor-alpha gene expression in human subcutaneous fat by lipid infusion. Diabetes 49, 319-324.

Nolan JJ, Olefski JM, Nyce MR, Considine RV \& Caro JF (1996) Effect of troglitazone on leptin production. Studies in vitro and in human subjects. Diabetes 45, 1276-1278.

Oliver P, Picó C \& Palou A (2001) Ontogenesis of leptin expression in different adipose tissue depots in the rat. European Journal of Physiology 442, 383-390.

Palou A, Serra F, Bonet ML \& Picó C (2000) Obesity: molecular bases of a multifactorial problem. European Journal of Nutrition 39, 127-144.

Perdereau D, Foufelle F, Gouhot B, Ferre P \& Girard J (1992) Influence of diet on the development and regulation of lipogenic enzymes in adipose tissue. Proceedings of the Nutrition Society 51, 387-395.

Perona JS, Portillo MP, Macarulla MT, Tueros AI \& Ruiz-Gutiérrez V (2000) Influence of different dietary fats on triacylglycerol deposition in rat adipose tissue. British Journal of Nutrition $\mathbf{8 4}$, $765-774$.

Portillo MP, Chávarri M, Durán D, Rodríguez VM \& Macarulla MT (2001) Differential effects of diets that provide different lipid sources on hepatic lipogenic activities in rats under ad libitum or restricted feeding. Nutrition 17, 467-473.

Portillo MP, Serra F, Simón E, Del Barrio AS \& Palou A (1998) Energy restriction with high-fat diet enriched with coconut oil 
gives higher UCP1 and lower white fat in rats. International Journal of Obesity 22, 974-979.

Portillo MP, Simón E, García-Calonge MA \& del Barrio AS (1999a) Effect of high-fat diet on lipolysis in isolated adipocytes from visceral and subcutaneous WAT. European Journal of Nutrition 38, 177-182.

Portillo MP, Tueros AI, Perona JS, Ruiz-Gutiérrez V, Torres I \& Macarulla MT (1999b) Modifications induced by dietary lipid source in adipose tissue phospholipid fatty acids and their consequences in lipid mobilization. British Journal of Nutrition $\mathbf{8 2}$, 319-327.

Raclot T, Groscolas R, Langin D \& Ferre F (1997) Site-specific regulation of gene expression by $n-3$ polyunsaturated fatty acids in rat white adipose tissues. Journal of Lipid Research 38, 1963-1971.

Reeves PG, Nielsen FH \& Fahey GC (1993) AIN-93 purified diets for laboratory rodents: final report of the American Institute of Nutrition ad hoc writing committee on the reformulation of the AIN-76 A rodent diet. Journal of Nutrition 123, 1939-1951.

Rodríguez VM, Portillo MP, Pico C, Macarulla MT \& Palou A (2002) Olive oil feeding up-regulates uncoupling protein genes in rat brown adipose tissue and skeletal muscle. American Journal of Clinical Nutrition 75, 213-220.

Saladin R, De Vos P, Guerre-Millo M, Leturque A \& Girard J (1995) Transient increase in obese gene expression after food intake or insulin administration. Nature 377, 527-529.

Sinha MK, Opentanova I, Ohannesian JP, Kolaczynski JW, Heiman ML, Hale J, Becker GW, Bowsher RR, Stephens TW \& Caro JF (1996) Evidence of free and bound leptin in human circulation. Studies in lean and obese subjects during short-term fasting. Journal of Clinical Investigation 98, 1277-1282.

Takahashi Y \& Ide T (2000) Dietary $n$-3 fatty acids affect mRNA level of brown adipose tissue uncoupling protein 1 , and white adipose tissue leptin and glucose transporter 4 in the rat. British Journal of Nutrition 84, 175-184.

Takeuchi N, Matsuo T, Toksyama K, Shimomura Y \& Suzuki M (1995) Diet-induced thermogenesis is lower in rats fed a larddiet than in those fed a high oleic acid safflower oil diet, a safflower oil diet or a linseed oil diet. Journal of Nutrition 125, 920-925.

Trayhurn P, Duncan JS \& Rayner V (1995a) Acute cold-induced suppression of $o b$ (obese) gene expression in white adipose tissue of mice: mediation by the sympathetic system. Biochemical Journal 311, 729-733.

Trayhurn P, Hoggard N, Mercer JG \& Rainer DV (1999) Leptin: fundamental aspects. Inernational Journal of Obesity 23, Suppl. 1, 22-28.

Trayhurn P, Thomas MEA, Duncan JS \& Rayner DW (1995b) Effects of fasting and refeeding on $o b$ gene expression in white adipose tissue of lean and obese mice. FEBS Letters 368, 488-490.

Villafuerte BC, Fine JB, Bai Y, Zhao W, Fleming S \& DiGirolamo M (2000) Expression of leptin and insulin-like growth factor-I are highly correlated and region-specific in adipose tissue of growing rats. Obesity Research 8, 646-654.

Wang J, Liu R, Hawkins M, Barzaiai N \& Rossetti L (1998) A nutrient-sensing pathway regulates leptin gene expression on muscle and fat. Nature 393, 684-688. 